\title{
PELATIHAN PEMBUATAN MEDIA PEMBELAJARAN ANAK USIA DINI MENGGUNAKAN BAHAN SISA
}

\author{
Nurhafizah \\ PG- PAUD, Fakultas Ilmu Pendidikan \\ Universitas Negeri Padang \\ Email : nurhafizah.is.87@gmail.com
}

\begin{abstract}
ABSTRAK
Tujuan kegiatan pelatihan adalah 1) Memberikan pengetahuan secara teoritis tentang pentingnya media pembelajaran bagi anak usia dini, 2) Melatih guru-guru dan pamong lembaga Pendidikan Anak Usia Dini Kecamatan Lubuk Alung dalam membuat media pembelajaran menggunakan bahan sisa. 3) Melatih guru dan pamong lembaga Pendidikan Anak Usia Dini Kecamatan Lubuk Alung menyusun Rencana Perangkat Pembelajaran Harian (RPPH) terkait media dari bahan sisa yang dibuat secara perkelompok, 4) Melatih guru dan pamong lembaga Pendidikan Anak Usia Dini Kecamatan Lubuk Alung mempraktekkan kegiatan pembelajaran menggunakan media dari bahan sisa yang telah dibuat secara perkelompok. Metode kegiatannya adalah : 1) Pelatihan secara teoritis tentang pelatihan media pembelajaran di lembaga Pendidikan Anak Usia Dini, 2) pelatihan pembuatan media dari bahan sisa, 3) pelatihan penyusunan Rencana Pelaksanaan Pembelajaran Harian sesuai dengan media yang dibuat. 4) Pelatihan praktek penggunaan media dari bahan sisa yang dibuat merujuk pada RPPH yang telah dirancang. Hasil yang diperoleh dari pelatihan adalah : 1) peningkatan pemahaman guru dan pamong tentang pentingnya media pembelajaran pada lembaga Pendidikan Anak Usia Dini. 2) Peningkatan kemampuan guru dan pamong dalam membuat media dari bahan sisa, 3) Rencana Pelaksanaan Pembelajaran Harian terkait media dari bahan sisa yang dibuat untuk pembelajaran di lembaga Pendidikan Anak Usia Dini, 4) peningkatan keberanian dan keterampilan mengajar guru dengan menggunakan media dari bahan sisa.
\end{abstract}

Kata Kunci: media Pembelajaran; bahan sisa; guru dan pamong; lembaga pendidikan anak usia dini

\begin{abstract}
The purpose of training activities is 1) Provide theoretical knowledge about the importance of learning media for early childhood, 2) Train teachers and tutors of the Early Childhood Education Institution in Lubuk Alung District in making learning media using residual materials. 3) Train teachers and tutors of the Early Childhood Education Institution in Lubuk Alung Sub-district to prepare Daily Learning Tool Plans related to media from residual materials made in groups, 4) Train teachers and tutors of the Early Childhood Education Institution in Lubuk Alung District to practice using learning activities media from residual material that has been made in groups. The activity methods are: 1) theoretical training on learning media training in Early Childhood Education institutions, 2) training in making media from residual materials, 3) training in the preparation of Daily Learning Implementation Plans in accordance with the media created. 4) Training on media use practices from residual materials made referring to the prepare Daily Learning Tool Plans that has been designed. The results obtained from the training were: 1) increasing the understanding of teachers and tutors about the importance of learning media in Early Childhood Education institutions. 2) Increasing the ability of teachers and tutors to make media from residual materials, 3) Daily Learning Implementation Plans related to media from residual materials made for learning in Early Childhood Education institutions, 4) increased courage and teacher teaching skills by using media from residual materials
\end{abstract}

Keyword: Learning Media; Waste material; Teachers and Civilians; Early Childhood Education Institute. 


\section{PENDAHULUAN}

Pendidikan merupakan proses pengembangan potensi manusia sepanjang hayat. Salah satu fase pendidikan itu adalah pada masa usia dini. Penegasan tentang pendidikan anak usia dini terdapat dalam Undangundang Sistem Pendidikan Nasional Nomor 20 tahun 2003 bagian ketujuh bahwa upaya pembinaan kepada anak itu sejak lahir sampai usia 6 tahun untuk membantu pertumbuhan dan perkembangan jasmani dan rohani agar anak memiliki kesiapan dalam memasuki pendidikan lebih lanjut, (Nurhafizah, 2015). Selain itu dalam UU Nomor 23 tahun 2002 tentang Perlindungan Anak (pasal 9 ayat 1) menjelaskan bahwa anak berhak memperoleh pendidikan dan pengajaran dalam rangka pengembangan pribadi dan tingkat kecerdasan sesuai minat dan bakatnya. Konsep umum undangundang Sisdiknas dijabarkan dalam kebijakan pemerintah di bidang kurikulum pendidikan anak usia dini, (Kepala Puskur Depdiknas RI; Bambang Indiarto). Kebijakan Diknas juga dikembangkan dengan Kurikulum tahun 2013.

Disamping kebijakan pemerintah, para ahli juga banyak berupaya mengembangkan bentukbentuk kecerdasan dan indikatornya, misalnya untuk Taman Kanak-kanak. Dalam mengembangkan bentuk-bentuk kecerdasan dalam pembelajaran diperlukan kemampuan pengetahuan yang baik dimiliki pada guru agar tujuan pembelajaran tercapai dan kemampuan serta potensi anak didik dapat berkembang maksimal, (Nurhafizah, 2017). Pendidikan di sekolah menjadi tanggung jawab guru. Proses pendidikan seharusnya dapat menjadi bekal untuk diterapkan dalam kehidupan anak di lingkungan masyarakat, (Nurhafizah, 2018).

Namun berdasarkan hasil
pengamatan yang dilakukan pada beberapa lembaga pendidikan anak usia dini, pada saat aktifitas observasi di kecamatan Lubuk Alung, proses pembelajaran masih terlihat belum maksimal. Misalnya masih banyak guru tidak menggunakan media dalam pembelajaran, anak belajar seperti layaknya anak-anak yang sudah berada di bangku pendidikan yang lebih tinggi. Guru tidak memahami bahwa penggunaan media sangat penting dalam pengembangan anak yang masih berada pada masa pra-operasional konkret, dimana penggunaan media dalam pembelajaran merupakan hal yang mutlak. Apabila kebutuhan anak dalam pembelajaran tidak terpenuhi, maka anak terlihat bosan dan enggan memperhatikan guru, sehingga pembelajaran yang dilakukan tidak efektif dalam pengembangan potensi anak. Selain itu, terlihat masih banyak guru belum dapat memilih metode pembelajaran yang sesuai, dan seringkali terlihat guru sangat minim dalam penggunaan media pembelajaran. Oleh karena itu maka diperlukan upayaupaya sistematis untuk mengatasi hal tersebut baik melalui strategi dan metode pembelajaran, maupun usaha- 
usaha lain seperti penyediaan lingkungan dan media yang menarik perhatian anak, dan tentu saja pengembangan kemampuan pembuatan media pembelajaran oleh guru.

Temuan-temuan tersebut, kemungkinan disebabkan karena sampai saat ini kemampuan guru atau pamong AUD dalam kemampuan pembuatan media khususnya media bahan sisa masih jarang dikembangkan, misalnya dalam bentuk pelatihan-pelatihan. Belum semua guru atau pamong memiliki latar belakang pendidikan yang mumpuni. Di beberapa lembaga pendidikan anak usia dini masih banyak guru atau pamong tamatan non pendidikan misalnya, hanya lulusan SMU sederajat bahkan ada yang hanya lulusan SMP dan Sekolah Dasar. Secara profesional mereka tidak memiliki keterampilan yang terlatih untuk membuat media pembelajaran yang kreatif, termasuk media bahan sisa untuk anak. Jadi, semuanya murni sharing dari guru senior kepada guru yunior. Kondisi lembaga pendidikan di lembaga PAUD seperti penjelasan di atas tidak perlu dipertahankan. Oleh karena itu pembenahan proses pembelajaran untuk lembaga-lembaga PAUD perlu segera dilakukan. Untuk melakukan perbaikan tersebut dibutuhkan keterlibatan lembaga-lembaga profesional termasuk perguruan tinggi.

\section{Pengertian Media Pembelajaran}

Schramm (1977) menjelaskan bahwa media pembelajaran adalah "teknologi pembawa pesan yang dapat dimanfaatkan untuk keperluan pembelajaran". Menurut Briggs (1977) mengemukakan bahwa media pembelajaran adalah "sarana fisik untuk menyampaikan isi atau materi pembelajaran seperti buku, film, video, slide, dan sebagainya".

Romiszowski dalam Basuki dan Farida (2001) media pembelajaran adalah media yang efektif untuk melaksanakan proses pengajaran yang direncanakan dengan baik. Azhar (2011) media pembelajaran adalah alat bantu pada proses belajar baik di dalam maupun diluar kelas, lebih lanjut dijelaskan bahwa media pembelajaran adalah komponen sumber belajar atau wahana fisik yang mengandung materi instruksional di lingkungan siswa yang dapat merangsang siswa untuk belajar. Menurut Arief Sadiman (2008) Media pembelajaran adalah segala sesuatu yang dapat digunakan untuk menyalurkan pesan dari pengirim ke penerima pesan.

Media belajar itu diperlukan oleh guru agar pembelajaran berjalan efektif dan efisien (Sutjiono 2005). Rayanda Asyar (2012) mengemukakan bahwa " media pembelajaran dapat dipahami sebagai segala sesuatu yang dapat menyampaikan atau menyalurkan pesan dari sumber secara terencana, sehingga terjadi lingkungan belajar yang kondusif dimana penerimanya dapat melakukan proses belajar secara efisien dan efektif. Syaful Bahri Djamarah dan Azwan Zain (2010) mengungkapkan bahwa media pembelajaran adalah alat 
bantu apa saja yang dapat dijadikan sebagai penyalur pesan agar tercapai tujuan pembelajaran.

Munadi (2008) mendefinisikan media pembelajaran sebagai segala sesuatu yang dapat menyampaikan dan menyalurkan pesan dari sumber secara terencana sehingga tercipta lingkungan belajar yang kondusif dimana penerimanya dapat melakukan proses belajar secara efisien dan efektif.

Media pembelajaran berfungsi bukan hanya sebagai sarana untuk membuat pembelajaran yang menyenangkan, tetapi juga membantu anak memahami sesuatu yang bersifat abstrak. Lebih jelasnya menurut Gerlach \& Ely (dalam Ibrahim, 2005) kelebihan media adalah : Pertama, memiliki kemampuan fiksatif, artinya dapat menangkap, menyimpan, dan menampilkan kembali suatu obyek atau kejadian. Dengan kemampuan ini, obyek atau kejadian dapat digambar, dipotret, direkam, difilmkan, kemudian dapat disimpan dan pada saat diperlukan dapat ditunjukkan dan diamati kembali seperti kejadian aslinya. Kedua, memiliki kemampuan manipulatif, artinya media dapat menampilkan kembali obyek atau kejadian dengan berbagai macam perubahan (manipulasi) sesuai keperluan, misalnya diubah ukurannya, kecepatannya, warnanya, serta dapat pula diulang-ulang penyajiannya. Ketiga, memiliki kemampuan distributif, artinya media mampu menjangkau anak didik yang besar jumlahnya dalam satu kali penyajian secara serempak.

Media pembelajaran yang baik adalah media yang dapat memberi kesempatan untuk mendapatkan dan memperkaya pengetahuan anak secara langsung. Dapat meningkatkan kemampuan berbahasa, berpikir kritis dan positif, membantu mengenal lingkungan dan kemampuan dirinya, menumbuhkan motivasi dan meningkatkan perhatian belajar pada anak-anak usia dini, guru profesional mesti memiliki pemahaman ini, Nurhafizah (2011).

Media tersebut harus memperhatikan keamanan, kebersihan, sesuai ukuran, bisa untuk bereksplorasi anak, dapat untuk bereksperimen anak, mengembangkan imajinasi anak, memotivasi anak untuk kreatif, mengembangkan kemampuan sosial anak, sesuai dengan tingkat perkembangan dan kemampuan anak, dan memiliki orientasi pada prinsipprinsip perkembangan anak.

\section{Media Pembelajaran dari Bahan Sisa}

Media pembelajaran di Taman Kanak-kanak sebaiknya dikembangkan sendiri oleh guru. Dalam kegiatan ini guru akan dilatih membuat media dari bahan sisa untuk dapat memvisualisasikan beberapa karakter ke anak didik. Pembelajaran menggunakan media dalam hal ini media dari bahan sisa langsung dapat mengoptimalkan fungsi seluruh panca indra anak sehingga meningkatkan efektivitas anak belajar dengan cara mendengar, melihat, meraba, dan menggunakan 
pikirannya secara logis dan realistis. Informasi tidak sekedar menerawang pada wilayah abstrak, melainkan sebagai proses empirik yang konkrit yang realistik serta menjadi bagian dari hidup yang tidak mudah dilupakan anak-anak. Tujuan penggunaan media langsung dalam hal ini media dari bahan sisa adalah untuk mendemonstrasikan konsep yang abstrak ke dalam bentuk visual.

Bahan sisa adalah bahan-bahan yang berasal dari barang-barang yang sudah tidak terpakai lagi, dan dapat didaur ulang kembali menjadi sesuatu yang bisa dimanfaatkan. Seperti : kertas bekas, koran, majalah, kardus, karton, kain, plastik, kaleng, styrofoam, busa, tali, tutup botol, sedotan, sendok es krim, botol plastik, keranjang buah dan karet. Sedangkan, Bahan alam adalah bahan-bahan yang berasal dari alam yang dapat diolah menjadi barangbarang yang bermanfaat bagi penggunanya. Seperti: batu-batuan, kayu, ranting, biji-bijian, daun-daun kering, pelepah, bambu, bunga, batang padi, dan lain-lain.

Tujuan dalam memanfaatkan bahan sisa dan bahan alam sebagai media bermain yaitu : Memperkaya atau menambah alat bermain sebagai sumber belajar, Memotivasi guru untuk lebih peka dalam mengoptimalkan lingkungan sekitar untuk dijadikan sebagai media bermain, Murah, mudah dan tersedia.

\section{Macam Bahan Sisa di Sekitar TK}

Beberapa bahan sisa yang dapat dimanfaatkan untuk media pembelajaran dan bermain diantaranya sebagai berikut:

- Kerta bekas (Koran, majalah, dan lain-lain.)

- Kardus atau karton.

- Bahan atau kain perca.

- Plastik dan kaleng.

- Styrofoam dan busa.

- Tali.

- Tutup botol dan karet.

- Stik es krim

Memanfaatkan bahan sisa sebagai media bermain tak luput dari memanfaatkan lingkungan sebagai sumber belajar dan tempat bermain anak. Sebab bahan sisa tersebut diperoleh dan didapat dari lingkungan. Oleh sebab itu, dituntut kreativitas guru dalam memanfaatkan lingkungan sebagai sumber belajar dan bermain bagi anak usia dini dengan menemukan media pembelajaran dari bahan sisa yang telah ada di lingkungan.

Adapun contoh bentuk pemanfaatan lingkungan sebagai sumber belajar dan bermain anak usia dini yaitu :

1. Mengolah dan memanfaat lingkungan menjadi alat permainan yang mendidik, Contoh :

$>$ Membuat mobil-mobilan dari kulit jeruk bali, batang pisang, dan lain-lain 
$>$ Membuat rumah-rumahan, bentuk-bentuk geometri dari kardus bekas

$>$ Membuat ayunan dipohon dari tali yang kuat

$>$ Membuat bola, bunga, topi dari kertas koran

$>$ Membuat pot dan bunga serta berbagai perhiasan kelas dari tutup botol dan bekas minuman lainnya.

$>$ Dan sebagainya

2. Memanfaat lingkungan secara langsung, seperti mengamati binatang, tumbuhan, batu-batuan, kejadian-kejadian alam (hujan, gerakan angin, air dan sebagainya), (Nurhafizah, 2017).

Maka pendidik diharapkan dapat manfaatkan berbagai jenis sumber belajar itu menjadi alat-alat permainan yang mendidik, dan bermanfaat untuk anak. Selain itu juga bisa membantu menyelamatkan bumi, dengan cara yang sederhana namun bermakna.

Adapun mitra dari kegiatan ini adalah kelompok guru dan pamong TK dan PAUD di kecamatan Lubuk Alung kabupaten Padang Pariaman. Jumlah guru kurang lebih 40 orang dan rata-rata berpendidikan Sekolah Lanjutan Atas (SLA) dan beberapa dari perguruan tinggi dengan berbagai disiplin ilmu. Selama ini guru dan pamong di TK/PAUD kecamatan Lubuk Alung sudah pernah mengikuti beberapa pelatihan namun belum pernah mengikuti pelatihan membeuat media secara spesifik khususnya media dari bahan sisa.
Pengadaan media sebagian besar dengan cara membeli ke toko mainan anak-anak. Akibatnya guru menjadi kurang kreatif dan kurang bisa mengembangkan diri. Dengan alasan keterbatasan biaya bahkan dalam mengajar guru tidak menggunakan media melainkan mengajar anak TK atau PAUD secara klasikal layaknya anak Sekolah Dasar (SD) yang tentu saja tidak sesuai dengan tahapan perkembangan anak. Dalam kegiatan sehari-hari pembelajaran disesuaikan dengan media yang ada, bukan media yang disesuaikan dengan kegiatan pembelajarannya. Seringkali, kalaupun ada media namun dipaksakan untuk menyampaikan sebuah pembelajaran meskipun kurang sesuai. Oleh karena itu kegiatan ini bertujuan untuk meningkatkan kreativitas guru atau pamong TK dan PAUD terutama dalam membuat media khususnya media dari bahan sisa di TK ataupun di PAUD.

\section{METODE PENELITIAN}

Memahami permasalahan pada lembaga PAUD di Kecamatan Batang Anai Kabupaten Padang Pariaman karena minimnya kemampuan dan kompetensi guru dalam membuat dan menggunakan media pembelajaran, sedangkan tuntutan untuk kualitas pendidikan semakin berat. Realitas ini mengharuskan para guru atau pamong memiliki keterampilan yang dapat merealisasikan kualitas pendidikan tersebut, salah satunya keterampilan pembelajaran dengan membuat dan 
menggunakan media untuk anak usia dini.

Untuk memecahkan masalah yang telah dikemukakan di atas, dan atas permintaan dari mitra yakni IGTK dan Himpaudi Kecamatan Lubuk Alung Padang Pariaman, dipilih alternatif kegiatan yang terbaik yaitu: diberi kesempatan untuk maksimal 40 puluh orang wakil dari lembaga PAUD di kecamatan Lubuk Alung Padang Pariaman melalui organisasi profesi IGTKI dan Himpaudi tersebut, untuk kemudian diberikan penyuluhan dan pengayaan materi terkait dengan media pembelajaran. Selanjutnya hasil penyuluhan direalisasikan dalam bentuk pelatihan dan pembimbingan membuat media pembelajaran khususnya media dari bahan sisa sekaligus tentang penggunaannya.

Adapun metode pelaksanaan pelatihan adalah berupa materi yang diberikan di lembaga PAUD Kecamatan Lubuk Alung Padang Pariaman:

1. Kegiatan penyuluhan dari nara sumber dalam rangka membekali wawasan peserta, terkait pentingnya Media dalam pembelajaran pada anak usia dini dengan berbagai pendekatan.

2. Kegiatan pelatihan pembuatan media pembelajaran pada anak usia dini khususnya pembuatan media dari bahan sisa.

3. Membuat satu buah satuan pembelajaran (RPPH) yang sesuai dengan media yang akan dibuat dengan tema dan sub tema yang disepakati kelompok.

4. Mendemonstrasikan penggunaan media pembelajaran yang telah dibuat dengan praktek langsung dalam kegiatan pelatihan. Selama proses praktek berlangsung, peserta dibimbing secara berkelompok maupun individu oleh instruktur dan tim pengabdian.

Dalam pelaksanaan kegiatan ini digunakan beberapa metode, yaitu:

1. Untuk pemberian informasi digunakan metode ceramah dimana para nara sumber menyajikan materi dan setelah itu dilakukan tanya jawab.

2. Untuk mengetahui penguasaan materi digunakan metode demonstrasi atau peragaan pembuatan media.

3. Metode praktek langsung membuat media dari bahan sisa oleh para peserta secara kelompok.

Metode simulasi penggunaan media bahan sisa yang telah dibuat sesuai RPPH yang telah dirancang secara kelompok.

\section{HASIL DAN PEMBAHASAN}

Hasil dari Pelatihan kemampuan membuat Media dari bahan sisa pada guru TK dan pamong PAUD Kecamatan Lubuk Alung Padang Pariaman antara lain :

1. Pembukaan acara dibuka langsung oleh Ketua organisasi IGTKI dan Himpaudi kecamatan Lubuk Alung. Acara juga dihadiri oleh Peserta 
Pelatihan terdiri dari kurang lebih 40 orang guru dan pamong perwakilan dari berbagai Taman Kanak-kanak dan PAUD yang ada di kecamatan Lubuk Alung

2. Materi yang disajikan adalah tentang Media pembelajaran, tutorial membuat Media dari bahan sisa dan praktek pembuatan RPPH sesuai dengan media yang dibuat serta praktek penggunaan media yang telah dibuat dalam pembelajaran dan simulasi secara kelompok.

3. Pelatihan berlangsung dengan lancar dimana pada tahap awal adalah kegiatan memotivasi para guru tentang pentingnya peranan media dalam pembelajaran pada anak usia dini khususnya di Taman Kanakkanak dan PAUD, serta menggugah guru untuk lebih kreatif dalam pembuatan media. Supaya pelaksanaan pelatihan tidak kaku dan tegang maka penyajian materi dibarengi dengan tanya jawab.

4. Pada saat pelatihan peserta begitu antusias mengikuti pelatihan karena pada sesi tanya jawab panitia menyediakan door prize bagi peserta yang menjawab dengan benar. Berdasarkan pengamatan pada saat pelatihan tidak ditemukan kendala yang signifikan, namun diharapkan adanya proses berkelanjutan untuk meningkatkan keterampilan dalam guru-guru dan pamong, karena tidak dapat diingkari bahwa pada prakteknya masih banyak guru yang tidak menggunakan media dalam pembelajaran pada anak usia dini padahal itu merupakan hal yang sangat esensial untuk memberikan pemahaman yang lebih utuh dalam mengembangkan kemampuan anak.

5. Hasil dari pengabdian ini guru dan pamong bertambah wawasannya terutama terkait pentingnya media pembelajaran, bagaimana membuat media-media yang lebih kreatif serta penggunaannya.

6. Peserta mampu membuat media dari bahan sisa sendiri yang dapat digunakan dalam menunjang semakin baiknya kualitas pembelajaran baik di Taman Kanakkanak maupun pada lembaga Pendidikan Anak Usia Dini yang lain.

7. Tercapainya target luaran berupa Publikasidi koran dan Publikasi Ilmiah berupa jurnal dan Penunjang buku ajar.

\section{SIMPULAN}

Strategi belajar mengajar perlu dirancang dan diterapkan guru ketika akan dan saat melaksanakan pembelajaran. Media pembelajaran adalah hal yang sangat penting dalam menunjang penerapan strategi pembelajaran tersebut. Dengan strategi pembelajaran yang baik, tentunya akan dapat dihasilkan hasil pembelajaran yang maksimal. Anak dapat belajar dengan nyaman, karena gurunya mengajar dengan menyampaikan pentingnya materi untuk kehidupan masa mendatang bagi anak, dan juga memahami bentuk-bentuk materi pelajaran yang disampaikannya. Dengan pemahaman ini, guru dapat menentukan strategi yang cocok dan 
sesuai dengan bentuk materi, dan ditunjang dengan penggunaan media pembelajaran yang sesuai.

Dari kegiatan Pelatihan yang dilakukan dan dari diskusi serta tanya jawab dengan guru dan pamong TK dan PAUD dapat diambil kesimpulan penyebab kurangnya kemampuan dalam pembuatan media pembelajaran khususnya media dari bahan sisa di kecamatan Lubuk Alung kabupaten Padang Pariaman, yaitu :

1. Tidak adanya acuan

2. Kurangnya wawasan dan pengetahuan

3. Ketidaksesuaian latar belakang pendidikan guru dan pamong

4. Rasio jumlah anak tidak sebanding dengan jumlah guru

5. Ketidaktahuan guru tentang pentingnya media pembelajaran dalam pendidikan anak usia dini

6. Kurangnya kemauan untuk meningkatkan kompetensi diri.

Tidak mau capek dan terbebani dikarenakan berbagai sebab salah satunya karena tidak sesuainya insentif yang diterima guru dan pamong TK dan PAUD.

\section{Saran}

Diharapkan adanya pelatihanpelatihan lanjutan untuk meningkatkan kemampuan para guru khususnya keterampilan dalam membuat dan menggunakan media pembelajaran.

\section{UCAPAN TERIMA KASIH}

Penulis mengucapkan terima kasih kepada Lembaga Penelitian dan Pengabdian kepada Masyarakat
Universitas Negeri Padang yang telah mendanai pengabdian ini melalui Dana PNBP Universitas Negeri Padang Tahun 2018 Dibiayai berdasarkan SK Rektor UNP, Nomor : 071/UN35/KP/ 2017 Tanggal : 3 Januari 2017 Universitas Negeri Padang.

\section{DAFTAR PUSTAKA}

Adrianto, dedy . 2011. Memanfaatkan lingkungan sekitar sebagai sumber belajar aanak usia dini. Direktorat pembinaan pendidikan anak usia dini : Jakarta

Arsyad, Azhar. 2011. Media Pembelajaran. Jakarta : Rajawali Pers.

Asyar, Rayandra. (2012). Kreatif Mengembangkan Media Pembelajaran. Jakarta: Gaung Persada Press.

Dzamarah, Syaful Bhari dan Arswan Zain. (2010). Strategi Belajar Mengajar. Jakarta: Rineka Cipta. Edisi Revisi.

Hamzah, B, Uno. 2007. Model

Pembelajaran, Menciptakan Proses Belajar Mengajar yang Kreatif dan Efektif. Jakarta: Bumi Aksara.

Miller, Susan. 1991. Learning Through Play Language ; A Practical Guide for Teaching Young Children. New York : Scholastic Inc., 
Nurhafizah. 2011. Kemampuan Berkomunikasi sebagai Pilar Profesionalisme guru dalam membimbing Anak Usia Dini. UPI: Bandung

Nurhafizah. 2015. Implementasi Permainan Tradisional Indonesia di Taman Kanakkanak kota Padang. Pedagogi Jurnal Ilmiah Ilmu Pendidikan, Volume XV Nomor 1.

Nurhafizah. 2017. Development of Naturalist Intelligence of Children in Kindergarten. Atlantis Press: Volume 169.

Nurhafizah. 2017. Strategi Pengembangan Sains Anak Taman Kanak-kanak di Koto Tangah Padang. Pedagogi Jurnal Anak Usia Dini dan Pendidikan Anak Usia Dini Volume 3 No. 3 b.

Nurhafizah. 2018. Bimbingan Awal Kewirausahaan pada Anak Usia Dini. Jurnal Konseling dan Pendidikan volume 6 No. 1

Pupuh dan Sobri, 2009. Strategi Belajar Mengajar. Bandung: PT Reka Jaya.

Rudi, S., \& Cepi, R. (2008). Media Pembelajaran. Bandung: Jurusan Kurtekpend FIP UPI.

Sadiman, Arif S. dkk. 2008. Media Pendidikan. Jakarta: PT Raja Grafindo Persada
Wibawa, Basuki dan Farida Mukti. 2001. Media Pengajaran. Bandung : CV Maulana.

Yamin, Martinus. 2003. Strategi Pembelajaran Berbasis Kompetensi. Jakarta: GP Press.

Yudhi Munadi. 2008. Media Pembelajran; Sebuah Pendekatan Baru. Jakarta: Gaung Persada Press

.

